\title{
Interpreting social issues: Museum theatre's potential for critical engagement
}

Niki Nikonanou*, Foteini Venieri**

\begin{abstract}
Museum theatre and its potential within museum education is explored at the Museum Education and Research Laboratory at the University of Thessaly, Greece. There, the leading research project Museums and Education: methods of approaching and interpreting museum objects'aims to address how, over the last few decades, museum theatre has been in ever-increasing use to vocalize the sensitive issues of a multicultural society and marginalized social communities. Recent studies highlight museum theatre evoking empathy and critical engagement in the audience with the subject-matter of the performance. One such performance was organized by the School of Drama at the Aristotle University of Thessaloniki and studied in depth. Titled Voices of the City: Historical Routes through Theatre, the performance embodied controversial social issues, and its implementation was evaluated using qualitative methodology to examine the responses of visitors.
\end{abstract}

Key Words: museum theatre, heritage performance, museum education, social issues, evaluation.

\section{Introduction}

The application of theatre and theatrical techniques for the interpretation of cultural heritage fits into the broader field known generically as 'museum theatre'. Museum theatre has grown considerably during the last decades, showing the capability to engage audiences in controversial social issues. This paper focuses on research undertaken by the Museum Education and Research Laboratory ${ }^{1}$ from 2012 to 2014 at University of Thessaly, Greece. The research project Museums and education: methods of approaching and interpreting museum objects sought to explore current museum educational practices in Greece and abroad, focusing on different methodologies applied in the context of museum interpretation.

Within this context, the project set out to:

- investigate museum theatre's potential to engage new audiences and make museums and monuments appealing to different social and age groups,

- examine the ways through which the public is involved in the interpretive process,

- explore museum theatre's ability to offer multiple narratives, challenging the museum's 'authority', and supporting its function as a space of experience, learning and entertainment.

The purpose of the research is to fill some gaps concerning the understanding of a highly complex instrument, such as theatre, in the museum environment. The challenging aspects between these two elements are the exploration of the reception processes of the theatrical phenomenon in the context of museums, while simultaneously taking into account current museological theory and practices.

The project involved the study and evaluation of a performance walk which aimed to interpret selected monuments of the city of Thessaloniki using exclusively theatrical methods. This paper presents the results concerning two main research questions explored: museum theatre's social impact and its potential in critically engaging the audience in the subject matter of the performance. 


\section{Museum Theatre and social impact}

Museum theatre may broadly be defined as 'the use of theatre and theatrical techniques as a means of mediating knowledge and understanding in the context of museum education' (Jackson \& Rees Leahy 2005: 304). By definition, museum theatre is an eclectic medium that draws from a significant variety of theatrical techniques and aligns them with the museums' respective goals.

Museum theatre can be a valuable tool in approaching a diverse audience that doesn't feel related to the cultural displays; It can aid interpretation, 'offering insights into the social meaning of artifacts', 'animating the inanimate' (Jackson and Kidd 2007: 2). Museum theatre's learning potential has also been highlighted, especially in terms of providing links to current personal, social and political realities, as well as in terms of revealing the complexity of museum narratives and allowing multi-vocal interpretations (Jackson and Kidd 2008).

During the last decades, museum theatre scholars have focused on museum theatre's potential to challenge what Smith defines as 'Authentic Heritage Discourse' (AHD): 'the dominant ways of thinking, talking and writing about heritage' (Smith 2011: 71). ${ }^{2}$ The use of verbal and non-verbal theatre techniques that project multiple perspectives, driven by choice, offers a free-zone in the construction of 'reality'. Thus, museum theatre can generate a multi vocal forum and give a voice to those whose voice has so far been neglected or distorted by the AHD. Furthermore, recent studies suggest that inviting visitors to reflect and challenge dominant narratives is an essential part of avoiding stereotypes and promoting a critical approach to the subject matter (Stoddard et al 2015).

Stereotypes are a part of peoples' cultural practices - beliefs, behaviors and attitudes - which create a main interpretive field for museum theatre. Cultural practices have been described as memes that form the 'intangible human remains' of a different era, developed in a different social, ethical and economic context, affecting contemporary social relationships. As Farthing (2011: 94-100) highlights 'memes are not always benign, so a critical perspective has to be established' through a dialogical space that opens up the potential of dynamic processes of making meaning.

Meaning making processes can be further enriched through the use of several important tools that are activated by museum theatre. The dramaturgical quality of 'heteroglossia' or 'multi-languaged discourse', is a powerful means of unsettling preconceptions; it goes further than multivocality by offering 'a clash of worldviews, often irreconcilable [...]. Consequently, the audience is allowed a real space in which to negotiate his or her own meaning from the narrative' (Jackson 2011: 21). In addition, historically, theatre possesses the quality of contextualizing information (or objects) 'intellectually, emotionally, socially, politically, spiritually and aesthetically' (Allsford and Parry 1991: 13), rather than merely supplying information. In a heritage context this quality can lead to a multi-level recontextualization of decontextualized objects and to an examination of 'contrasting values' (Shackel 2006).

Museum theatre also transforms the nature of heritage visits at the museum by establishing a shift from individual to collective experience, as the research project Performance, Learning, Heritage has proven (Rees Leahy 2011: 29). Collective experience, a fundamental trait of theatre, contributes to the formation of social and collaborative environments where 'situated learning takes place' (Stoddard et al 2015: 128). This transformation also involves a shift in habitus, according to the definition provided by Pierre Bourdieu in The Logic of Practice: Habitus is essentially the way in which the culture of a particular social group is embodied (internalized) in the individual, during the socialization process beginning in early childhood. Habitus is 'society written into the body, into the biological individual' (Bourdieu 1990: 53).

An interesting implementation of this concept is found at the Lower East Side Tenement Museum, where museum theatre is a main interpretive means. Chalfen states that the

the museum suggests that it is through a physical experience that culture can become a force of social transformation, meeting and challenging our habitus where our sociological codes are physically enshrined. The target is to effect social change through kinaesthetic experience (2011: 222). 
Nevertheless, the use of theatre in museums and heritage sites has been a highly contested practice. One major argument is that 'dramatic reenactment can distort people's understanding of the past since that past can never be fully reproduced' (Hughes et al. 2007: 6). Despite the justified concerns regarding the multiplicity of ways museum theatre can possibly be implemented, this argument also raises the issue of 'being true to recorded history, which by definition is a severely limited version of the "past" itself' (Hughes et al. 2007: 6). Jackson et al suggest that this opposition is the result of the "distrust of the fictionalizing effect of museum theatre' due to 'a refusal to acknowledge the role of the subjective, the arbitrary and the expedient in the construction and narration of history throughout the museum' (Jackson et al. 2002: 4). The fictional nature of museum theatre may indeed lead to misinterpretations (Maggelsen 2007). On the other hand, however, these objections also imply 'a fundamental distrust of visitors' ability to rationalize and critique what they are seeing' (Hughes et al. 2007: 6 ) especially when museum theatre becomes a process that challenges the roles established for non-expert users of heritage (Smith 2006: 34).

Museum theatre has also proven to be a valuable tool in promoting emotional engagement (Hughes 2008, Jackson \& Kidd 2008). On the basis of the acknowledgement of the vital role emotions play in museum visitors' experience (Falk \& Dierking 2000, Hughes 2008: 22), museum theatre can offer 'a site of affective and cognitive processing' (Hughes: 2008: iii).

In sum, museum theatre has shown the potential to promote critical thinking on social issues. Its effectiveness lies not only in including the audience, as observers, but in activating the audience too by challenging established modes of thinking and acting. In order to do so, museum theatre means to provoke and offer a chance for reflection through the creation of a dialogical space where multiple perspectives can unravel. The contextualization of objects and issues as well as the inclusion of heteroglossic elements appear to be of high importance in achieving the above aims. The theoretical approaches stated above highlight the importance of a research project directed towards museum theatre implementations in Greece, in order to cover a gap in research in the field. A presentation of the research results follows.

\section{Case Study: Performance walk 'Voices of the city'}

From November 2012 through March 2013 a performance walk titled Voices of the City. Historical routes through theatre, was implemented in Thessaloniki's historical centre as part of commemoration events of the centenary of Thessaloniki's liberation from Ottoman rule. The performance walk was designed and implemented by Ms Avdi and Ms Hatzigeorgiou, who are in charge of the 'Theatre in Education' course at the Department of Drama, University of Thessaloniki. Voices of the city' was presented twice a week mainly to secondary school groups as well as to groups of educators. In total, there were 1030 participants in the performance walk, 700 of which were school students and 330 adult participants, who were mainly teachers (Avdi et al 2013; Avdi and Hatzigeorgiou 2014).The interpreters were drama students close to graduation and recent graduate actors and actresses who were not in costumes unless otherwise stated.

Voices of the city' was selected as the main case study of the research project because of its originality: it is the first educational program aiming to exclusively interpret the history of the city by deploying short theatrical performances at selected monuments. ${ }^{3}$ The performance walk aimed at enforcing active citizenship and giving prominence to the city's multicultural identity through the centuries. Thus, immigration and its social impact were highlighted throughout.

Lasting for 2.5 hours, the performance walk included six site-specific presentations, each employing different theatre techniques. All the sites chosen represented historical landmarks of different eras and were situated in the centre of Thessaloniki, very close to one another. The atmosphere of the performance was generated by its location, since the city's centre is like an open-air museum, landscaped and full of monuments dating from the Roman era until the recent past.

The first performance took place in the courtyard of the Byzantine church of St. Demetrius, a church dedicated to the patron saint of Thessaloniki. Constructed in the fourth century AD, the church rose at the time when Thessaloniki was the second largest city in the Byzantine 
Empire and it still stands today as a landmark of contemporary Thessaloniki. As a significant part of the city's identity, the church courtyard offered a starting point for the narrative of the city's history that began in $315 \mathrm{BC}$. Through the use of storytelling, first person interpretation and short performances, interpreters highlighted key events of the city's history until its liberation from Ottoman rule in 1912, underlining its rich cultural heritage.

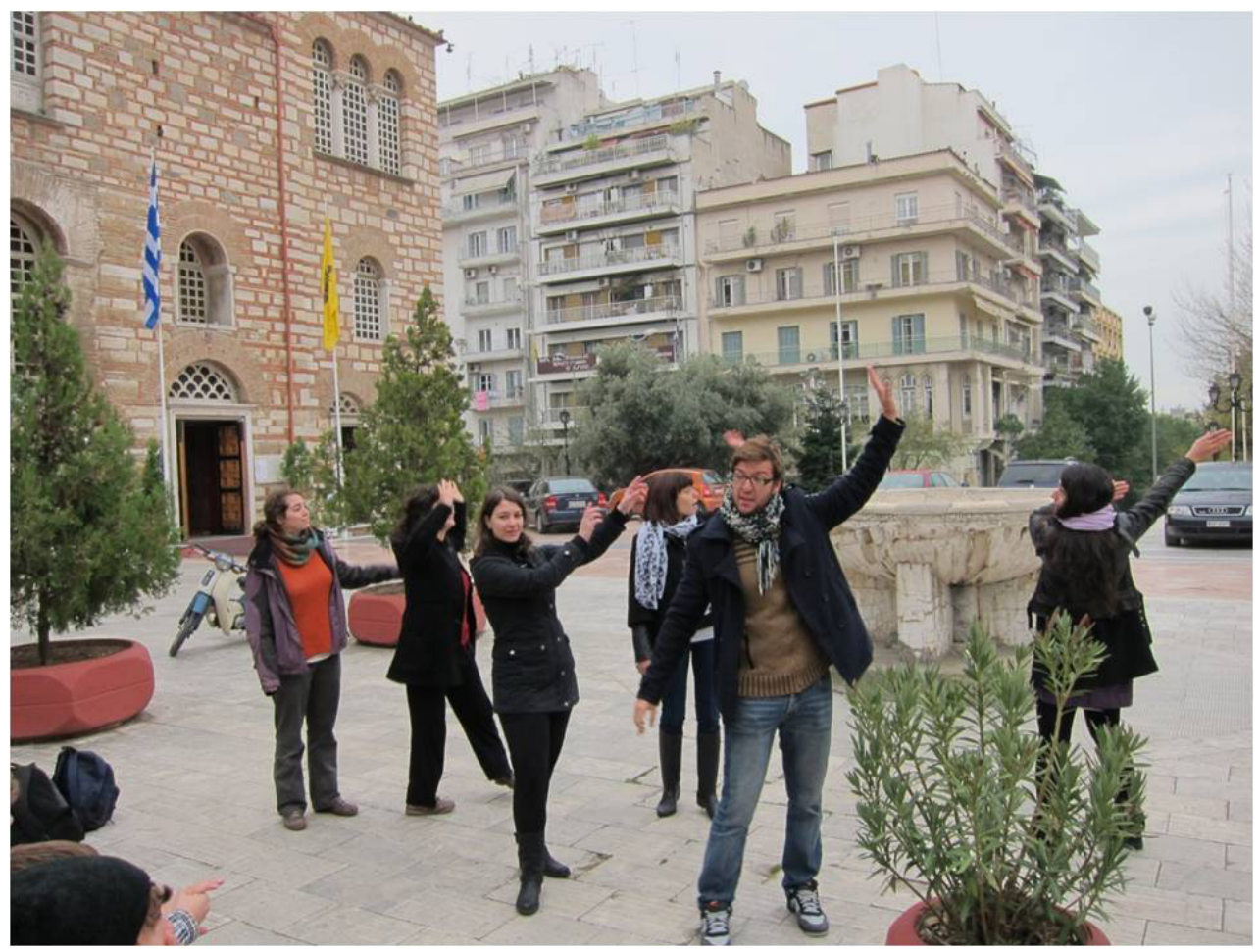

Fig 1. St Demetrius Church

Firstly, interpreters introduced themselves and commented on their favorite experience in the city. Then, a storyteller imitating the attitude of a traditional teacher started narrating key aspects of the city's history: its foundation, its main characteristics in different eras, its strong multicultural character during the Ottoman rule and its lasting traits throughout the centuries. Short theatrical sketches interrupted and animated the teacher's narrative, filling it with events, stories and myths. The storyteller also referred to the church's history and in that framework a short scene depicting an annual feast of the twelfth century honoring St Demetrius was performed and supported by the use of objects. The performance closed with a reference to the diverse cultural sites and monuments of the city. During the performance three open-ended questions addressed to the audience aimed to link audience's experience to the issues raised by the performance: How might living in a multicultural city might have felt like? What is a monument? What does a monument 'mean' to us? Rhetorical questions focusing on concepts of citizenship were also addressed.

The second performance took place at the park situated in front of the Labor Union Centre. The Labor Union Centre was founded in 1917 and played a vital role in the history of the Greek workers' movement. In the 1930s, a mass protest for workers' rights which was violently attacked by the police formed one of the most significant moments in its history. The performance focused on a worker's murder during the protest, which also inspired a major Greek poet, Giannis Ritsos, to write one of his most prominent poems called 'The Epitaph'. The description of massive demonstration was performed through story telling while the scene of the dead man's mother reaction was enacted in the first person by an actress-interpreter. 


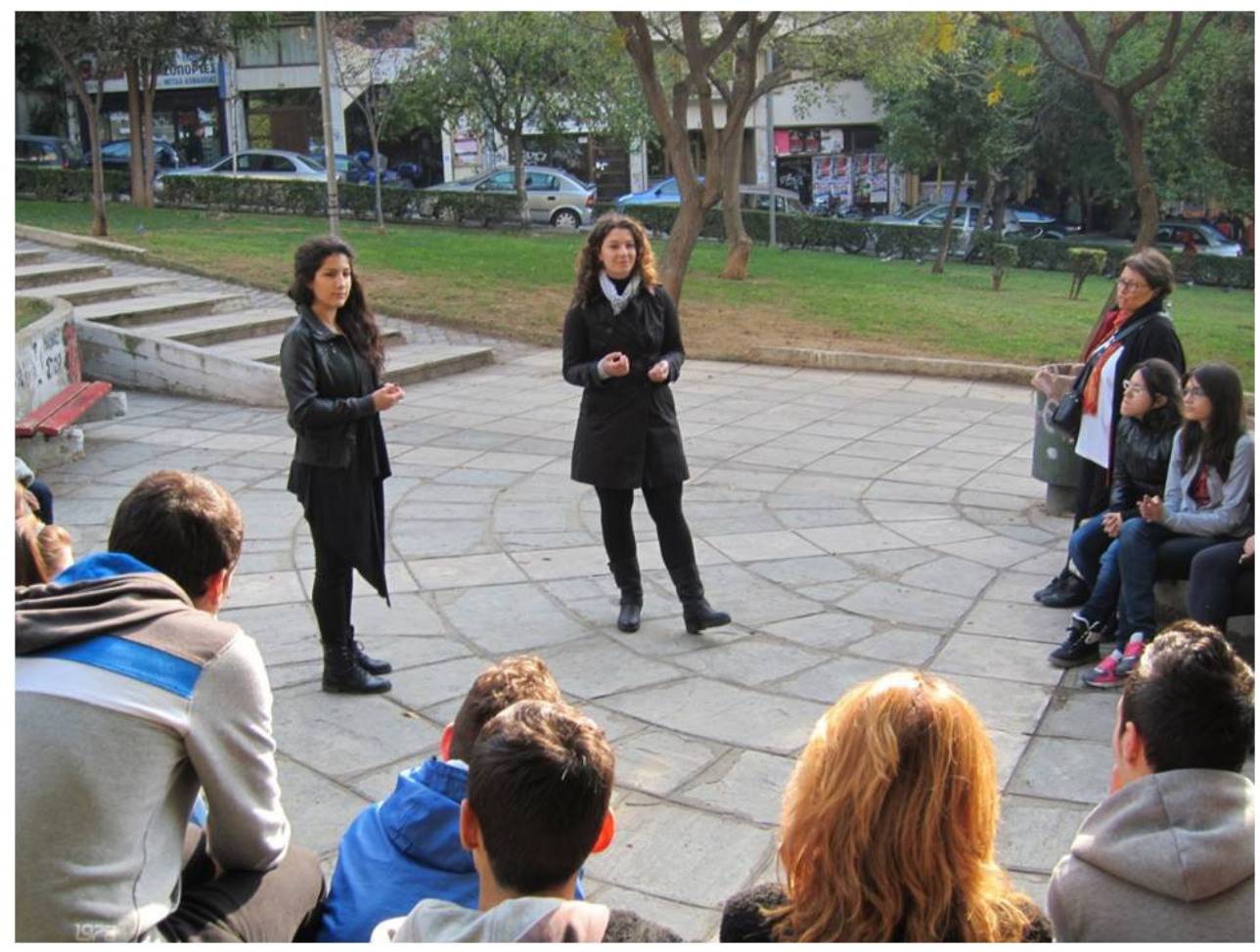

Fig 2. Labor Union Square

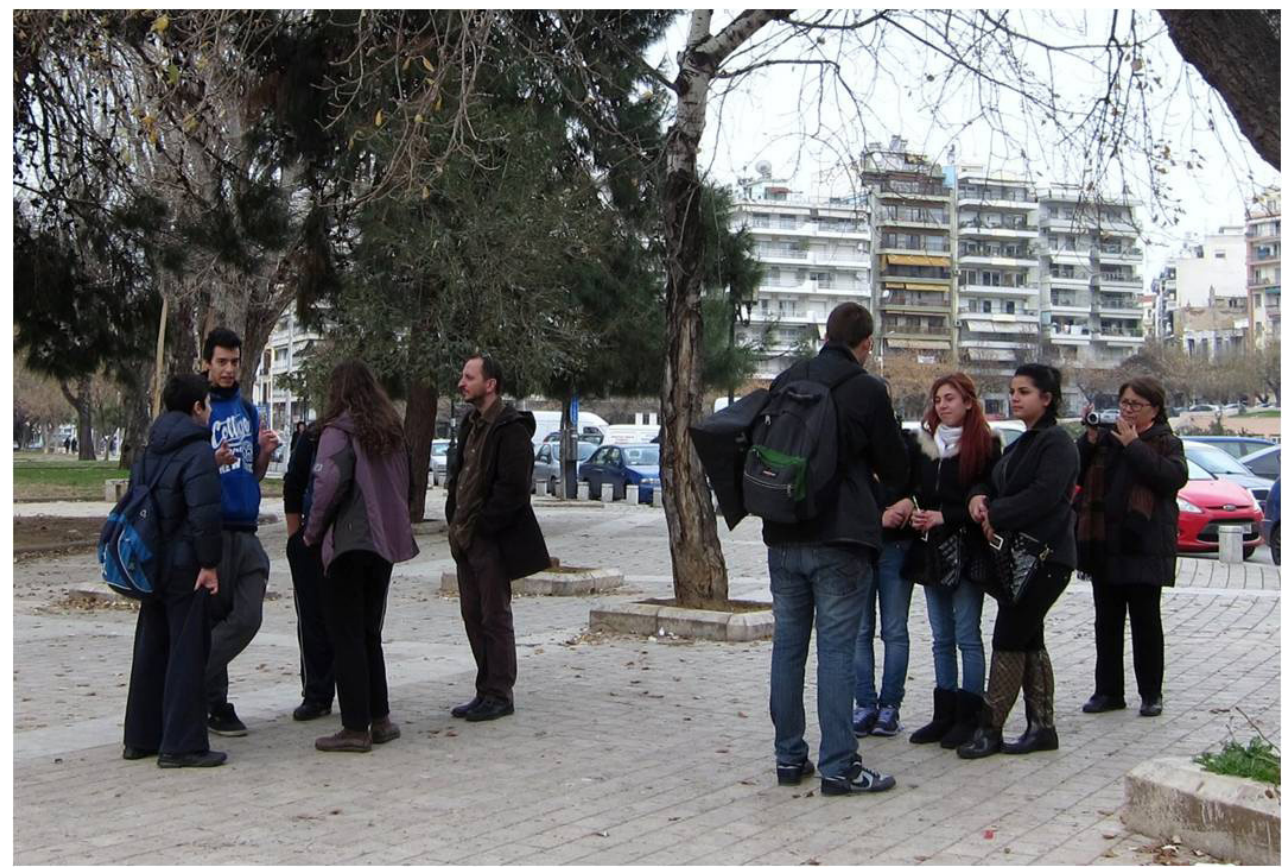

Fig 3. Court Square: contemporary immigrants 
The third performance was implemented at the Court Square, a place which has preserved a multicultural character throughout the centuries. Today it is still a common meeting point for immigrants. Its intertemporal identity as a gathering place of various ethnic and cultural groups provided a direct link to the multicultural traits of the city and proved to be an ideal place to communicate the lives and difficulties of today's immigrants. Through the use of an interactive first person interpretation, interpreters in role of contemporary immigrants approached the students, who were split in groups of $4-5$ persons, and shared their life histories and difficulties while asking for the student's advice. In the majority of these 'meetings' students were actively participating by trying to figure out a solution. In this part of the performance students (audience) and interpreters create the space of communication. At this point in the performance, interactivity between the audience and the stage is being encouraged, coaxing viewers to contemplate solutions to the problems on hand. It also exposed the multiple dimensions of the immigrants' problems which are at the same time personal, social, psychological, affective and financial.

The experimental school of Thessaloniki was the next performance's site. The site's significance derives from the fact that its foundation in 1935 and ongoing presence until the present day is strongly linked to the Greek progressive education movement. The main characters of the performance were the two major representatives of this movement, Alexandros Delmouzos and Miltos Kountouras, who lived in the first half of the twentieth century and were derided for their ideas and practices. During an interview taken in front of the school's entrance by an interpreter in the role of a journalist of the era, the educators had the chance to develop their educational principles and comment on the difficulties they faced. The audience stood in front of the interpreters and its presence was acknowledged, but there was no interaction between them at this point. At the end of the performance, the students were led in front of the sculptures of the two men situated nearby and were proposed questions concerning their views on the current educational system, compared to the ideas they had just heard.

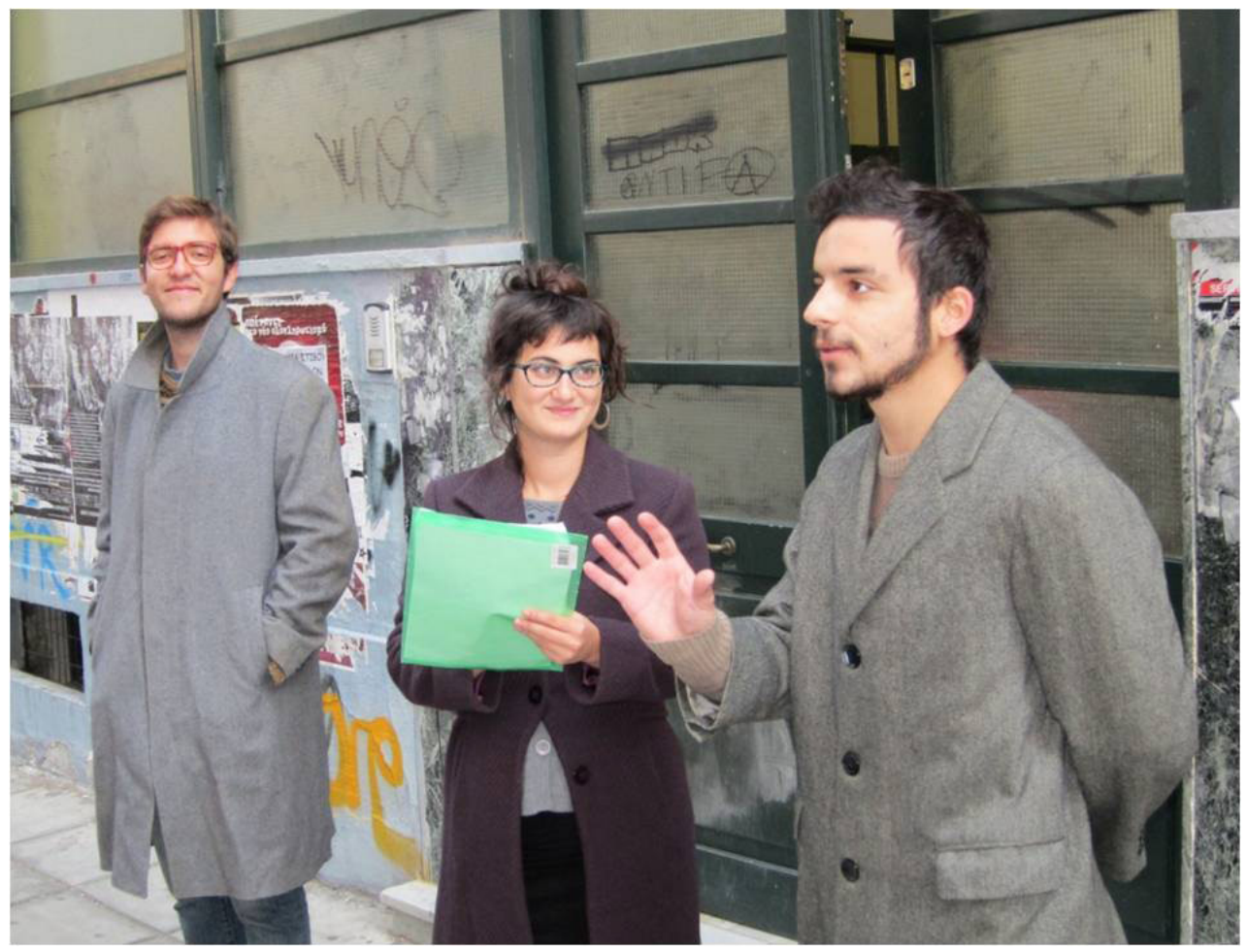

Fig 4. Experimental School: An interview with the educators 
The fifth performance took place at the courtyard of the Byzantine church of Panagia Acheiropoietos where Greek refugees had settled in 1922 after the Asia Minor Holocaust. Panagia Acheiropoietos was the only church which hosted refugees during that time and so it was the chosen location to highlight the refugee's status at the beginning of the century. A short introduction referring to the church's history preceded the performance. Following, the audience watched a scene of the everyday life of the refugees during their stay in the church performed at the church's courtyard. Interpreters in the refugees' roles expressed a feeling of nostalgia for the life they were forced to abandon and they commented on the problems they encountered during their stay in the city: racism, extremely low-wages, homelessness, poverty, and child labor. The scene ended with a song, sung by the refugees. The performance adopted a traditional form without any interaction with the audience and made use of costumes, objects and live music, played by the interpreters-in-role.

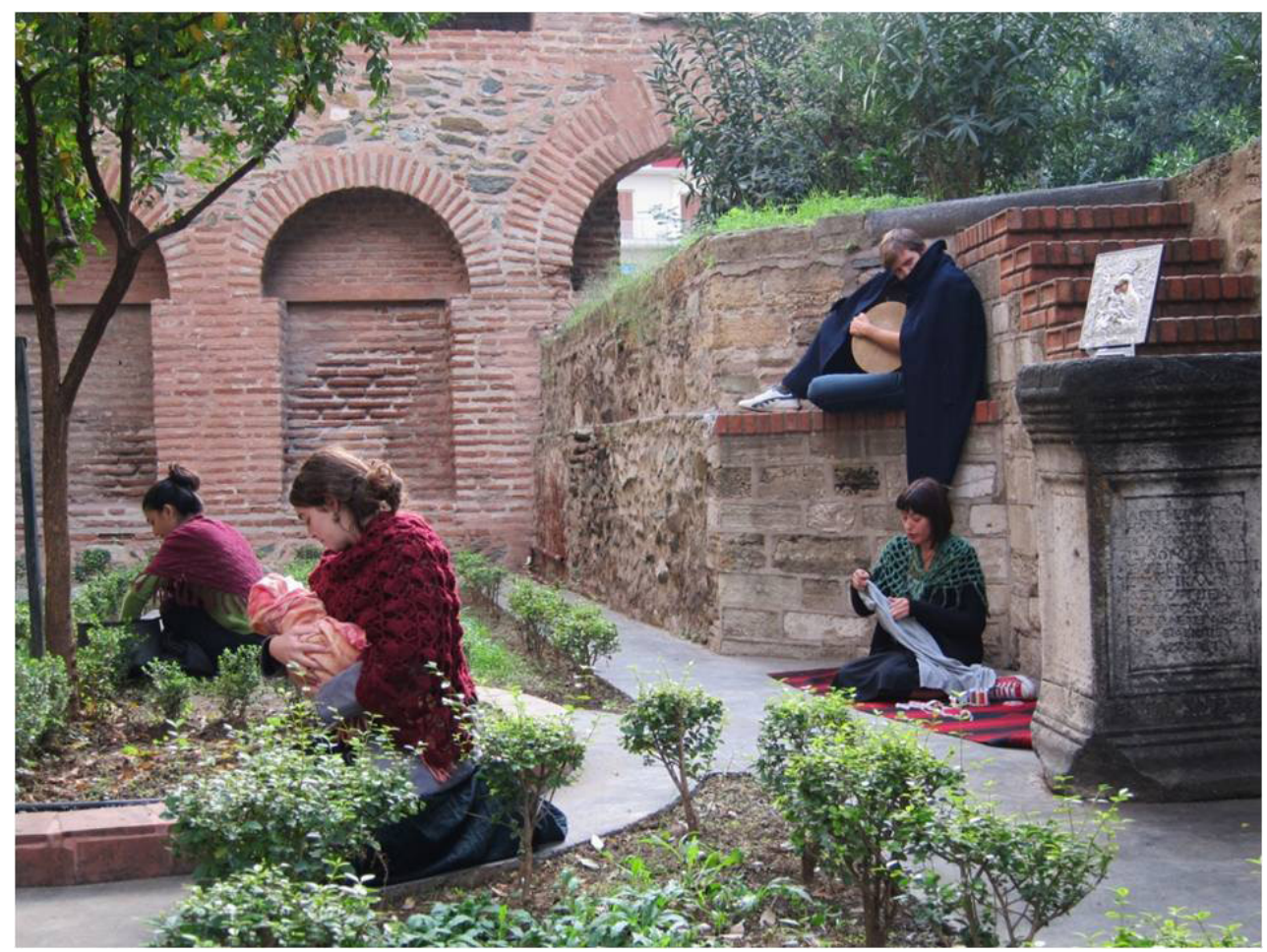

Fig 5. Acheiropoietos Church: the refugees' scene

After the performance, students were led to the church's entrance where the storyteller initiated a 'questions and answers' session around the refugees' contribution to the city, its acknowledgment by the citizens, and the preconceptions that surround refugees and immigrants both in the past and the present. It is worth mentioning that the 1922 Asia Minor refugees are nowadays recognized for the multiple ways they enriched Greek heritage; a very different approach to the one adopted when they first arrived.

The terrace of Bey Hamam, a bathhouse of the Ottoman era, was the setting of the sixth and final performance. Bey Hamam is the only Hamam of the city which is preserved and is open to visitors. At this performance, the themes explored were the multicultural heritages including the Ottoman, Jewish, and Greek communities, as well as the attitudes of active citizens. This final performance was similar in both technique and structure to the first performance that took place at the Byzantine church of St. Dimitrios. Storytelling was interrupted by short theatrical performances but dance and songs were also added in the last performance. The 
narrative started with Bey Hamam's history and a reference to the few Ottoman monuments preserved. ${ }^{4} \mathrm{An}$ interpreter in the role of a liberal politician and founder of the city's university at the beginning of the twentieth century gave his opinion on the importance of the Ottoman heritage that had to be preserved. After his speech the storyteller informed the audience that the 'Thessaloniki International Fair', an event once very popular, was founded in 1926. She then addressed the audience with rhetorical questions on the development of the fair, its present impact and its perspectives for the future. The story of the elimination of the Jewish community during World War II followed. The storyteller introduced the theme and refered to the humiliating practices imposed onto the Jewish as well as to their mass deportation. She also refered to their settlement in Thessaloniki in the fifteenth century and their contribution to the city's heritage. Interpreters in role of the Jewish people animated the narrative, wearing a yellow star on their shirts and singing a Jewish song as they walked to the train station in order to be transferred to the concentration camps. The storyteller continued her narrative with the departure of the German troops from the city in 1944 and the people's expressions of enthusiasm as they 'run in the streets, hugging one another'.

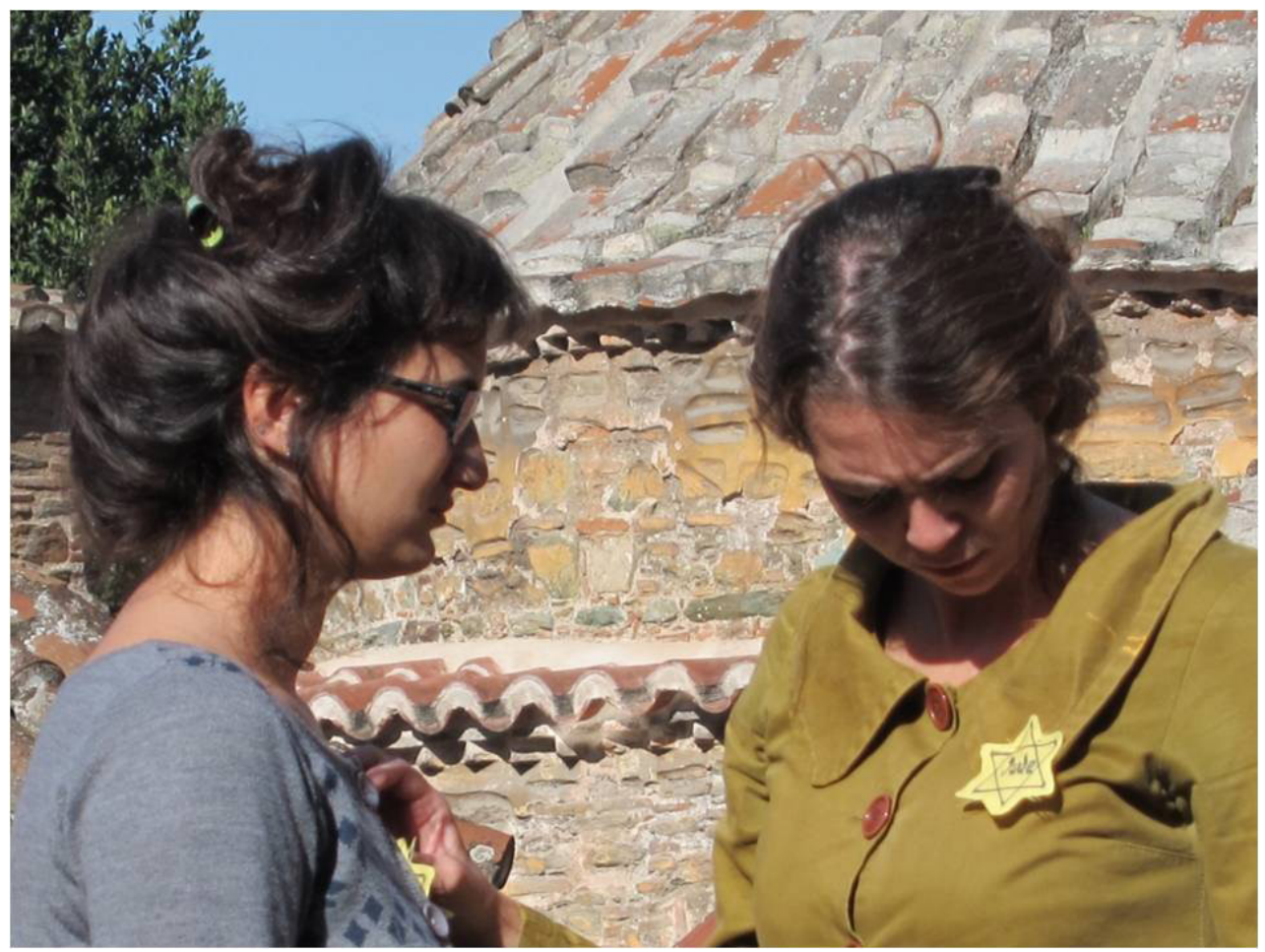

Fig 6. Bey Hamam: The Jewish scene

At this point interpreters posed rhetorical questions to the audience about the city's contemporary role and its relationship to the past. The questions were followed by a small performance by two female interpreters, one of whom represented a woman from the 1950's and the other a contemporary woman. They both sat in the café and without talking they tried to fix each other's gestures according to what was considered proper for their time. A musical piece accompanies the performance and when the performance ends interpreters address questions of the audience regarding the changes the city has gone through: its contemporary identity, its relationship to the citizens and the citizen's contribution to the city. The audience provides some short answers but no conversation is taking place. The performance ends with a rap song that commemorates all the city's citizens that have made a contribution. 
The performance walk was followed by a meeting of the school group with a prominent citizen of the present. The discussions between the citizen and the students were usually in the form of an interview, covering mainly the citizen's life.

In whole, the performance walk explored the city's history by referring to a variety of events that had taken place since its foundation. Two of the six performances focused on the issue of immigration and refugees creating a thematic entity that was concrete and clear. The rest of the short performances touched a variety of issues that were put under the concept of citizenship and community.

\section{Research methodology}

The initial aim of the research project was to explore the perception of the performance's content and form by the audiences-school groups. The variety of techniques and methods employed during the performance walk allowed the examination of the different impact level each short performance generated. As the research process was evolving, the need to focus on museum theatre's potential for critical engagement with social issues was addressed: the performance walk carried a socially sensitive narrative by interpreting the past of the city around a basic axis that highlighted personal stories during some politically and socially troubled times. The interpreted histories reached the recent past of the city, potentially touching some of the audience's familial memories, while the performance walk constituted an approach to the citizens' collective memory and consciousness. In the light of the theoretical context provided above, the effect of such a narrative could only be fruitful if it could, not only include, but activate the audience too, in order to critically approach the complexity of the subject matter, unsettle preconceptions coming from 'benign memes' and, subsequently, challenge established modes of thinking and acting. However, the performance and learning experience are two aspects that dynamically interact with the aspect of critical engagement in social issues, providing two important frames for the perceptive experience of the performance walk. Thence, the performance and learning experience formed two basic research objectives that significantly influenced audience's critical engagement with the social issues addressed during the performance.

In terms of epistemology the research followed a hermeneutic approach. The methodology was based on a qualitative approach. Three methodological tools were used during the implementation of the research project:

- Observation and documentation of the school groups' reactions, both verbal and non-verbal, during the performance. In whole, observation covered $1 / 3$ of the performances (13 performances).

- Impression sheets supported the documentation of audience's impressions after the performance. Impression sheets were given to the students by their teachers; they were filled in the classroom the day after the performance experience. In total, eleven school groups returned their impression sheets to the researchers.

- Interviews:

a) Semi-structured interviews with the interpreters and the performance's designers were conducted after the end of the performances.

b) Interviews were also conducted one year after the performance experience:

i) in focus groups with school students (who had also provided the impression sheets data).

ii) semi-structured interviews with the school groups' teachers.

Four school groups took part in the focus groups interviews. The longitudinal examination of these specific school groups' experience examined their observation and impression sheets data as well, in order to define their responses in different phases of the research.

The data that were drawn from the research process were grouped into the following categories:

- Performance experience

- Social impact and critical engagement 
- Learning ExperienceSocial impact was explored following the 'generic social outcomes'. ${ }^{5}$ Specifically, research focused on two out of the three outcomes suggested:

- Stronger and Safer Communities

- Strengthening Public Life

The exploration of critical engagement was intertwined within the above categories.

Data were examined through closed and open coding following the grounded theory model, which allows the emergence of a new theory from empirical data through an inductive methodology. Longitudinal audience research was conducted in order to gauge effectiveness and impact over the longer term. The research results presented in this paper will focus on the performance's social impact.

\section{Research results: School group responses}

The research project received feedback on Voices of the city'from approximately 150 audience members. Longitudinal research largely confirmed the immediate responses given and allowed their in-depth examination. For the purpose of this paper we will highlight some of these findings indicating the ways in which different individuals have been making sense of the social issues raised during the performance.

The majority of participants talked very positively about their experiences of the performance. The third and the fifth performances, which covered the issues of contemporary immigrants and Asia Minor refugees (the present and past of immigration), proved to be the most memorable and impactful. Concepts of citizenship explored throughout the performance were also highlighted in students' responses.

In the framework of 'stronger and safer communities', students' responses fall in the following categories:

- Improvement of group and inter-group dialogue and understanding

- Supporting cultural diversity and identity

- Encouraging familial ties and relationships

- Tackling the fear of crime and anti-social behavior

As far as it concerns the improvement of group and inter-group dialogue and understanding, students had the chance to co-operate and develop critical thinking during their meeting with the contemporary immigrants:

When they played the immigrants, they told us real stories, they made us think what we would decide...this is something everybody is going to remember. ${ }^{6}$

I found out that the immigrants that I see every day around me are struggling and working hard, even harder than the citizens, but they are not paid accordingly. ${ }^{7}$

They (the immigrants) made me feel concerned by asking questions and they made me think of the ways that we could solve the problems we talked about. ${ }^{8}$

In terms of supporting cultural diversity and identity, students' responses revealed an enforcement of cultural identity linked to the city's past, an acknowledgment of the difficulties that people encounter in the present due to their cultural and social status, as well as an acceptance of cultural difference:

I felt excited that I live in a city with such an important history and the people had so many difficulties and I can call them 'ancestors' with pride. ${ }^{9}$

I was impressed that still today kids from other countries are facing racism. This has to stop. ${ }^{10}$ 
I learnt that loving someone, no matter his/her colour or nationality, can unite us. It can make us better persons. ${ }^{11}$

In this context, responses revealed a thought-provoking process as well as the challenging of stereotypes.

I didn't feel sad....but I felt that out there are really people that go through these problems and we don't even care, we don't even think on that, we have a responsibility for that. ${ }^{12}$

...l accepted difference. ${ }^{13}$

Moreover, performances provoked consciousness through empathy concerning the immigration issue:

They wanted to remind us that the Greeks themselves were immigrants throughout their history ...so we should accept the immigrants and stop blaming them. ${ }^{14}$ However not all responses indicated a will for change or action but they did prove empathy, which was often limited to sadness:

I felt sad for the situation that refugees faced and the inhuman behavior of the citizens towards them. ${ }^{15}$

I felt sad and moved during the refugee's scene. ${ }^{16}$

An interviewee noted that during the contemporary immigrants' scene she felt 'closer' to the issue presented, indicating a combination of empathy and a will for action:

I felt they needed our help and that we have to find a way to help them since they ask for that, we have to tell them something. We felt closer. ${ }^{17}$

In terms of encouraging familial ties and relationships, students' responses related the refugee's scene with the stories they had heard from their relatives:

It reminded me of some personal moments with my grandma who told us stories about the war, I remembered when we were discussing all these with my family. ${ }^{18}$.

I was impressed by the refugee's scene...I liked that personally because I have heard many stories on that from my relatives. ${ }^{19}$

Tackling the fear of crime and anti-social behavior, in our case, concerns the attitude towards the immigrants; immigrants are very often identified as illegal while they are considered as the primary suspects in cases of criminal attitude, falling under a stereotyped attitude that runs through the past and the present of the city's recent history. Students' responses proved an acknowledgment of racism as the main source of hostility against them and claimed that the performance helped them in the exclusion of fear directed against this specific social group:

I felt strange and changed my mind about the immigrants. ${ }^{20}$

I think that racism, as it was experienced by the refugees, still exists towards the immigrants. ${ }^{21}$

A teacher's response confirmed the outcome:

They (the students) changed their mind. Some of them stopped being suspicious against them (the immigrants). ${ }^{22}$

In the framework of 'strengthening public life', responses fall under the following categories:

- Encouraging and supporting awareness and participation in local-decision making and wider civic and political engagement

- Building the capacity of community and voluntary groups 
Student's responses were found to be encouraging and supporting awareness and participation in local-decision making and wider civic and political engagement:

I thought that if everyone helped for making our city a better place everything would be better. ${ }^{23}$

I want to learn about my city and help my city as a member of a group. ${ }^{24}$

Regarding building the capacity of community and voluntary groups, students showed a will to work collectively in order to create valuable experiences.

It would be interesting to organize events in the city as a school group and activate ourselves as citizens. ${ }^{25}$

'I thought that it's time to get up and start learning history, things that happened and still happen in our city. And that we should make a change to our era. On our own and all together we should create something for the future. ${ }^{26}$

Overall, the performance walk proved to be of use and great effect in dealing with challenging and difficult content. It was especially effective, as Jackson and Kidd (2008:134) have highlighted, 'in instigating, framing and hosting debate and dialogue and gave a new-found appreciation of the complexity of the subject matter'. We may underline that the program contributed to the promotion of awareness and participation in a political debate and fostered the formation of political consciousness.

\section{Conclusions}

The examination of museum theatre's impact in promoting social and political consciousness related to the issues of immigration and citizenship revealed the complexity of the subject matter as well as museum theatre's ability to generate a critical approach under certain conditions.

Two parts of the performance walk proved to promote significant engagement: the immigrants and the refugees' scene (the third and fifth short performances). In the immigrants' short performance at the Court square, the first person interpretation technique combined with a strong interactive element among a small audience group proved to have a lasting effect in engaging the audience; it was the only performance that sparked conversation among the group members by stating some of the immigrants' real-life problems in the present. The voices of a largely marginalized group were heard and audience members were encouraged to offer their personal view on the possible ways an immigrant can face and deal with everyday difficulties in the contemporary social context. The immediacy of the performance gave a chance for immigrants' voices to be heard in a way that wouldn't be feasible in everyday life. Immediacy was further intensified by the formation of small audience groups. The audience members did empathize with the immigrants, but still most of them distanced themselves in order to figure out a solution. The audience's habitus' were challenged since most of them admitted in their long-term responses that they were given a unique chance to speak with an immigrant on his/her problems, as they would hesitate doing that in real life. Last but not least, the performance had a very strong element of action: the issues stated by the 'immigrants' involved an active dimension in the 'here and now' and required an active way of thinking from the part of the audience.

On the other hand, the 1922 refugees performance at the church of Panagia Acheiropoietos represented a closed narrative, did not offer any dialogical space, nor did it contain multiple perspectives. Nevertheless, it did offer a link to the previous contemporary immigrants' scene by unveiling the similarity of the problems encountered, as a result of certain cultural practices and beliefs, no matter the immigrants' or refugee's ethnicity, language or religion. ${ }^{27}$ In this way, claims of cultural incompatibility that form the base of racist speech today could be deconstructed.

The combination of the performances offered the audience the opportunity to make a link between the past and the present. It is worth noting that both performances were the only 
ones that clearly raised the same issue, offering an intertemporal exploration. The exploration could be further enriched with the addition of a de-briefing part. Audience's active engagement during the contemporary immigrants' performance enhanced critical thinking and challenged stereotypes. The performances' sequence seemed to have aided the contextualization of the subject matter from the part of the audience whose internalization of the subject was made apparent through audience response sheets and focus groups interviews. The fact that the refugees' performance followed the contemporary immigrants' performance of the 1922 refugee settlement promoted a link to an experience today's citizens are more familiar with. It would be interesting to examine to what extent and in what ways the sequence of the different forms employed during the performances affected the audience's engagement. Additionally the audience frequently mentioned the refugees' performance in Panagia Acheiropoietos, specifically recalling the incorporated objects and music. The recollection of the performance costumes and objects on part of the audience suggests that the combination of visual and affective stimuli during a performance can enhance internalization and aid recall.

It is interesting, though, that the rest of the short performances had a minor apparent impact or no impact at all. Emotional and intellectual engagement on social issues was expected in two more performances yet surprisingly they received minimal response. The performance at the Labour Union square was the first to receive very little feedback from the audience. The low response rate is surprising since the Labour Union Square performance conveyed the murder of a protester and his mother's reaction - content that is directly relevant to modern Greek reality. Despite its strong affective context and evident links to current events in Greece, the performance was not mentioned by the audience either in immediate or in long term responses. A reminder during the focus group interviews was necessary in order for a discussion to be generated. ${ }^{28}$ An equally strong affective element was embedded in the Jewish elimination scene at Bey Hamam, yet insubstantial short and long term responses were elicited from the audience as well. Notably, this scene did not have a setting that linked artifacts or related material remnants, suggesting the lack of substantial input from the audience may be attributable to the scarce visual stimuli of the setting. Additionally, the Jewish elimination scene was one of many scenes part of the last performance, the whole of which proved to be unmemorable for the viewers. Perhaps the absence of a dialogical space between the interpreters and the audience as well as the inclusion of many different scenes and many different issues prevented contextualization on the part of the audience.

The fourth short performance featuring the interview of the two progressive educators at the experimental school was also a scene with content highly related to current events but also elicited minimal viewer responses. Despite the immediate links it provided to the problems and perspectives of the modern educational system which would normally be one of the audience's concerns, the performance didn't prove to be thought-provoking in creating that link. After a reminder of the scene during the focus group interview, the only comment expressed referred to the educators' 'austerity' as well as to the obsolescence of the scene depicted. The way interpreters chose to portray the educators seemed to have a counter-effect on audience's engagement.

The same phenomenon of minor audience response was also encountered at the first performance in St Dimitrios church's courtyard. The audience could only visually recall the scenes that made use of objects, but neither short nor long term memory was recorded in audience responses regarding the subject matter. The two performances, in St Dimitrios church's courtyard and in Bey Hamam respectively, provided a density of cognitive information on several issues which seemed to prevent their contextualization. The abundance of information seemed to create an overloaded combination for the audience to internalize. However, the open-ended questions at the end of the performance in Bey Hamam regarding the concept of citizenship in general, as well as the conversation with a prominent citizen immediately after the performance, did have an impact. Active engagement with the subject matter in the form of verbal interaction seemed once again to have had a decisive influence on the negotiation and re-examination of both main issues that arose during the performance walk. Due to the dialogical space created, at the end of the performance walk and during the contemporary immigrants' performance at the Court Square, the audience was engaged in a dynamic process of meaning-making. The audience's involvement in the process of making-meaning resulted 
in increased awareness of the issue and stimulated challenging of stereotypes. Multivocality through the voices of a variety of people that were represented during the performance walk was not remembered in detail, however the performance walk achieved a portrayal of the city as a mosaic of different realities and perspectives, according to the audiences' immediate and long-term responses. Still it remains unclear whether the element of heteroglossia was effectively embedded in the performances' narratives, as no evident 'clash of worldviews' was documented in viewer responses.

In summary, the research has shown that focusing on specific issues in combination with the use of first person dialogical interpretation, costumes, objects, and music significantly enhances engagement and critical thinking on the subject-matter. Multivocality can still be promoted through an exploration of subject matter with multiple perspectives, such as immigration, so long as a dialogical space is created. This dialogical space is what allows for multilayered and in-depth reflection to ensue from the audience, even when the subject matter is delivered in a close narrative form.

The inclusion of direct links to present day reality as well as to similar and familiar past phenomena can lead to a re-examination of the 'intangible human remains' and challenge stereotypes. The performance of 'unusual' practices from the part of the audience, such as a friendly conversation with a member of a marginalized community, creates a new physical experience, thus challenging an audiences' habitus. At the same time, a great amount of cognitive information delivered in the limited time of a performance without the inclusion of a dialogical space may lessen the learning and engagement potential of a museum theatre program. Research has also shown that engagement has often a strong emotional feature that can lead to a critical approach and to a will for change; however this is not always the case as the emotion of sadness without any further intellectual engagement on the subject matter was also documented. A further exploration of this finding would be useful in understanding the links between emotional and intellectual engagement and, particularly,-taking into account the variety of emotional responses- between specific emotions and their intellectual impact..

Furthermore, the addition of a more focused de-briefing part, in order to promote an 'adequate follow-up', which is especially vital when dealing with sensitive issues (Jackson and Kidd 2008: 137), could significantly fill the gaps of contextualization and foster critical engagement. Nevertheless the dialogical spaces created during the performance contributed towards these goals without fortification of de-brief sessions, reducing periods of engagement between actors and audience to only a part of the performances presented.

Overall, research suggests that theatre as a means of interpretation of cultural heritage has the potential to be a dynamic tool for dealing with social issues offering the option to present them both in their complexity and clarity. Utilized appropriately, theatre can deliver cultural heritage for interpretation beyond awareness of an issue, but further into critical and emotional engagement in cultural issues, often leading to activation of viewers into contemplating and trying to solve these issues that shape modern life in a multicultural society.

Received: 17 December 2015

Finally Accepted: 20 February 2017

\section{Acknowledgements}

We are grateful to Mrs Avdi and Mrs Hatzigeorgiou for offering us the chance to implement some research on their project. Thanks are due to the interpreters, to the teachers and to the students that kindly participated in the research process.

\section{Notes}

1 http://museumedulab.ece.uth.gr/main/en accessed 25 July 2015. The research project was funded by University of Thessaly's Research Committee.

2 Authentic Heritage Discourse' (AHD) excludes the sense of 'action' or critical engagement on the part of non-expert users of heritage, as 'heritage is about receiving the wisdom and knowledge of historians, archaeologists and other experts' (Smith 2006: 34). 
3 Thessaloniki's museums also offer an insight into different historical periods and ethnic groups (i.e. the Byzantine Museum, the Jewish Museum) but there is a lack of exhibitions concerning the city's recent history.

4 After the city's liberation from the Ottomans in 1912 the focus on ancient heritage was dominant and monuments of later eras were disdained. Thus, most of them were destroyed.

5 http://www.artscouncil.org.uk/advice-and-guidance/inspiring-learning-all-home-page, accessed 17 June 2016.

6 Student, interview by Foteini Venieri, digital recording, 2 May 2014, Thessaloniki, Second Experimental Secondary School.

7 Student, interview, 2 May 2014.

8 Student, interview, 2 May 2014.

9 Student, interview by Foteini Venieri, digital recording, 30 April 2014, Thessaloniki, Music High School.

10 Student, interview by Foteini Venieri, digital recording, 29 April 2014, Thessaloniki, 19th High School.

11 Student, interview, 30 April 2014.

12 Student, interview, 2 May 2014.

13 Student, interview, 30 April 2014

14 Student, interview, 30 April 2014.

15 Student, interview, 30 April 2014.

16 Student, interview, 30 April 2014.

17 Student, interview by Foteini Venieri, digital recording, 28 April 2014, Thessaloniki, Model Experimental School of the University of Thessaloniki

18 Student, interview, 30 April 2014.

19 Student, interview, 2 May 2014

20 Student, interview, 28 April 2014.

21 Student, interview, 29 April 2014.

22 Teacher, interview by Foteini Venieri, digital recording, 2 May 2014, Thessaloniki, $2^{\text {nd }}$ Experimental Secondary School.

23 Student, interview, 30 April 2014.

24 Student, interview, 30 April 2014.

25 Student, interview, 28 April 2014.

26 Student, interview, 30 April 2014.

27 The 1922 refugees were Greek Christians; however they were also treated with as much hostility as present-day immigrants who do not share the same language or religion as the Greeks. 
28 In 2008 extensive riots had taken place all over Greece due to the murder of a 15 year old boy by a policeman. The incident and the reactions it engendered are still a point of reference among Greek citizens. Furthermore protests in Greece have become very common in the last few years due to the financial crisis, and police brutality is a common phenomenon.

\section{References}

*Indicates references in Greek.

Alsford, S. and Parry, D. (1991) 'Interpretive Theatre:Arole in Museums?', Museum Management and Curatorship, 10, 8-23.

*Avdi, A. and Hatzigeorgiou, M. (2014) 'Voices of the City. Historical routes through theatre: A different promenade through the city's streets'. Skini, 6, 168-180. Available at: http:// ejournals.lib.auth.gr/skene/article/view/4501, accessed 6 December 2015.

Avdi, A., Chatzigeorgiou, M., Nikonanou, N. and Venieri, F. (2013) ' "Voices of the city. Historical Routes through Theatre". Presentation of an educational project and evaluation of students' involvement' Paper presented at IMTAL Global Conference, Washington DC, 09 /10/13. Available at: http://fwnes.tumblr.com/paper-IMTAL-2013, accessed 16 July 2016.

Bourdieu, P. (1990) The Logic of Practice, Stanford, California: Stanford University Press.

Chalfen, J. (2011) 'Performing human right at two historic site museums', in. Anthony Jackson and Jenny Kidd (eds) Performing Heritage. Research, practice and innovation in museum theatre and live interpretation, 220-233, Manchester and New York: Manchester University Press.

Farthing, A. (2011) 'Authenticity and Metaphor: displaying intangible human remains in museum theatre', in Anthony Jackson and Jenny Kidd (eds) Performing Heritage. Research, practice and innovation in museum theatre and live interpretation, 94-106, Manchester and New York: Manchester University Press.

Jackson, A. (2011) 'Engaging the audience: negotiating performance in the museum', in Anthony Jackson and Jenny Kidd (eds) Performing Heritage. Research, practice and innovation in museum theatre and live interpretation, 11-25, Manchester and New York Manchester University Press.

Jackson, A. and Kidd, J. (2008), 'Performance, Learning, Heritage' Final Report, Manchester University. Available at: http://www.plh.manchester.ac.uk/documents/Performance,\%20 Learning\%20\&\%20Heritage\%20-\%20Report.pdf , accessed 11 July 2016

(2007), "Museum Theatre": Cultivating Audience Engagement - a case study. Paper presented at IDEA 6th World Congress, Hong Kong, 21/7/07. Available at: http://www.plh. manchester.ac.uk/documents/Eng\%2024 Museum $\% 20$ theatre $\% 20 \% 28$ IDEA\%29\%20 \%282\%29.pdf , accessed 07 July 2016.

Jackson, A. and Rees Leahy, H. (2005) 'Seeing it for real...? Authenticity, theatre and learning in museums', Research in Drama Education, The Journal of Applied Theatre and Performance, 10 (3) 303 - 325.

Jackson, A., Johnson, P., Rees Leahy, H. and Walker, V. (2002) 'Seeing it for real:An investigation into the effectiveness of theatre and theatre techniques in museums', Manchester, England: Center for Applied Theatre Research, University of Manchester. Available at: http://www. plh.manchester.ac.uk/documents/Seeing_It_For_Real.pdf. accessed 7 July 2015 
Hamant, J. (1988) ‘Debut of Fairbooth Theatre’, Colonial Williamsburg, xi, 19-21.

Hughes, C., Jackson, A. and Kidd J. (2007) 'The Role of Theater in Museums and Historic Sites: Visitors, Audiences and Learners', International Handbook of Research in Arts Education, 16, 679-699.

Krasner, D. (ed) (2008), Theatre in Theory: An anthology, Chicago: Blackwell Press.

Maggelsen, S. (2006) 'Making History in the Second Person: Post-touristic Considerations for Living Historical Interpretation', Theatre Journal, 58 (2) 291-312.

Rees Leahy, H. (2011), 'Watching me, watching you: performance and performativity in the museum', in Anthony Jackson. and Jenny Kidd (eds) Performing Heritage. Research, practice and innovation in museum theatre and live interpretation, 26-38, Manchester and New York: Manchester University Press.

Smith, L. (2011) 'The 'doing' of heritage: heritage as performance', in Anthony. Jackson and Jenny Kidd (eds) Performing Heritage. Research, practice and innovation in museum theatre and live interpretation, 69-81, Manchester and New York: Manchester University Press

(2006) The Uses of Heritage, London and New York: Routledge

Stoddard, J., Marcus, A., Squire, K. and Martin, J. (2015) 'Learning Local Immigration History In and Out of the Museum', Museum \& Society, 13 (2) 123-141.

*Niki Nikonanou is Assistant Professor of Art History and Museum-Education at the Department of Early Childhood Education, University of Thessaly, Greece. She has studied German Language and Literature (BA), Art History (MA) and Museum-Education (PhD) at the Aristotle University of Thessaloniki (Greece) and at the University of Cologne (Germany). Her research interests include the theory and practice of museology, museum-education and communication, evaluation of educational activities. She is the author of the book Museum Education: from theory to practice (in Greek) (Patakis Publications, Athens) and a co-author of "Voices from the Museum: Survey Research in Europe's National Museums" (Linköping University Electronic Press, 2012).

Postal Address:

Department of Early Childhood Education

Argonafton \& Filellinon,

38221 Volos,

Greece

Telephone number: 00306932045300

niknik@ece.uth.gr

**Foteini Venieri is a PhD Candidate at the University of Thessaly, Greece. Her thesis focuses on the use of theatre as an interpretive means in museums and heritage sites. She holds a BA in Theatre Studies (Department of Theatre Studies, University of Athens) and has acquired her master degree on Cultural Management (Panteion University) as a scholar of State Scholarship Foundation of Greece. She is awarded scholarships from the Leventis Foundation and the A. Papadakis Foundation for conducting her PhD thesis. She is a member of the International Council of Museums, the International Museum Theatre Alliance, the Hellenic Theatre Studies association and the Hellenic Theatre/Drama Education Network.

Postal address:

Dimofontos 176-178, 11852,

Athens,

Greece

Telephone number: 00306936899598

fvenieri.cmc@gmail.com 